\title{
Women as Fighters for their Land Freedom In Wa Thiongo's A Grain of Wheat (1967)
}

\author{
Azeema Saad Al-Afifi \\ Department of English, Faculty of Arts, Port Said University
}

\begin{abstract}
This paper is planned to show how A Grain of Wheat (1967) epitomizes the Africana womanist vision. It attempts to sketch out the Africana womanist mottos that are adopted by Kenyan female figures within the Emergency period (1952-1962); a stage before Kenyan Independence. In this concern, it pays abundant attention to the cause of Kenyan women during that time and uncovers the conditions they have been put inside. Kenyan women have suffered under inimical situations and unfavorable provocations which could not be easily. Still, illuminated by the Africana womanist principles, Kenyan women have been able to persist and demonstrate their distinct capacities. With regard to this, the present paper tries to pinpoint all the aspects of domination they have been yoked by in the years preceding Independence, on the basis of Hudson-Weems' Africana Womanism hypothesis. It gets into consideration some of the particular Africana notions embodied certain elements such as the women harmony, the collective resistance to Africana patriarchal reality, the reverence for the aged, the female fellowship, the spirit of concerted enterprise, and certainly some of Kenyan female merits. These aspects are to be thoroughly examined to prove the relevance of Wa Thiongo's Africana views throughout the Emergency phase.
\end{abstract}

Keywords: A Grain of Wheat, Wominism, mottos, freedom.

\section{Introduction}

In the Preface of Secret lives, Wa Thiongo empirically encapsulates the contemporary obstacles Kenyan females have faced at the time:

As I write I remember the nights of fighting in my father's house; my mother's struggle with the soil so that we might eat, have decent clothes and get some schooling; my elder brother, Wallace Mwangi, running to the cover and security of the forest under a hail of bullets from colonial policemen; his messages from the forest urging me to continue with education at any cost; . . . uncles and other villagers murdered because they had taken the oath; the beautiful courage of ordinary men and women in Kenya who stood up to the might of British imperialism and indiscriminate terrorism .... I remember the fears, the betrayals, Rachael's tears, the moments of despair and love and kinship in struggle and I try to find meaning of it all through my pen. (Wa Thiongo n.p.)

Principally, the fundamentality of society is one of the main convictions of the Africana womanist body which is rendered in A Grain of Wheat. In this respect, the book seems to be dissimilar to Weep Not, Child. In the former, there exists a shattered African human community, while in A Grain of Wheat the people are united so that they can obtain the Kenyan Independence. On this ground, the latter is not related through a one-toned mode of narration, however, the novel includes the discourses of a multitude of men and women who gather themselves under one flag to end the occupation of their homeland. In experience, Independence cannot be reached by a society whose members are disseminated. Hence, the Kenyan community should have struggled relentlessly so as to gain liberty and freedom. Further, the movement of the Africana womanists has urged the public to "disengage themselves from the hostility, jealousy, and competition with one another that has kept . . . [them] vulnerable, week, and unable to envision new realities" (Allan 88). Being one of the Africana womansit novelists, Wa Thiongo emphasizes the substantial necessity of settling any kind of national disputes that may have disconnected the Kenyan society members so as to restore Kenyan autonomy - providing the people with a spirit of patriotic sensibility.

\section{Analysis}

The idea of the national fight for liberation is one of the fundaments of Wa Thiongo's womanist doctrine in A Grain of Wheat. The novel is grounded on the feminist belief that the backbone of Independence lies in establishing a collective and common public target. This fact might have made, Wa Thiongo, the man and novelist, influentially portray the Africana females and their unparalleled gifts which have enabled them to work 
perseveringly, and collaboratively with their Africana companion, for attaining a public freedom. A Grain of Wheat directs much attention towards the postulate that societal struggle is often rewarded by a country's Independence which has seemed far from achievable but for the females' cooperation, a prominent attribute of Hudson-Weems' Africana Womanist movement. As such, it manifests the militant identity of Kenyan females who are fighting bravely against imperialism so that they can rescue their lands. To put it lucidly, Africana men-women harmonious teamwork inspires Wa Thiongo's Africana womanist philosophy, one whose perspective is founded upon the unity of Africana males and females. Such view is established through Hudson-Weems' emphasis that "[w] must understand that we, Africana men and women, are in this together. We need to recognize that we are each other's better half, and that we need each other in order to work through this crisis" (Africana Womanist 96).

All throughout the plot of A Grain of Wheat, Wa Thiongo builds bonds between the characters' present and their memories in order to celebrate the sacrifices of the patriotic champions who willingly lose their lives that their land become free. James Ogude claims that "Ngugi recognizes the link between history and fiction. Indeed, for Wa Thiongo, the narrative is a tool for shaping, ordering, and reinterpreting history" ("Ngugi's concept" 88). Thus, the book introduces Africana characteristics who are endowed with the sense of national effort, being purged of the spirit of egotism. Wa Thiongo's making up of Kihika, for instance, becomes the emblem of the public sensibility. Kihika is the epitome of potential and quest of every citizen to redeem their colonized country. He always thinks of how to rescue all the Africana people. Also, Wa Thiongo expresses cordial respect for dedicating himself and his life for the national cause. By introducing Kihika, Wa Thiongo illustrates the womanist thought that the unity of the country's natives is the key to gaining an inclusive Independence. Leslie Monkman declares:

[T]he possibility of rebirth and growth lies not on the elevation of heroes and condemnation of villains from the past but in the union of all men in an objective recognition of their interdependence and of their common potential for future achievement. Kihika's significance lies not just in his own actions but in the accomplishments which his actions can inspire. (113)

The Kenyan womanist unity has led to the establishing of the Mau Mau group. Mau Mau revolution is one of the national parties that have been formed in the Emergency period to assist the Black natives to regain their seized country. The English settlers have usurped their country and abused its wealth to financially satisfy their greed. This certainly produces a bad influence generally on the Kenyan community and specifically on women. Illustratively, A Grain of Wheat censures robbing the property of the Kikuyu tribes who "were agriculturists," and "lost over sixty thousand acres to the settlers mostly in southern Kiambu, a highly fertile region outside of Nairobi that would become some of the most productive European farmland in the colony" (Elkins 12).

This paper, hence, gives prominence to the sincere and heroic deeds done by Kenyan women in collaboration with Kenyan men, and their unmatched endeavor to accomplish freedom and autonomy. It registers the innumerable championships Kenyan females have performed to achieve their country's self-control. A Grain of Wheat, as a womanist work, contains the daring, defiant and the other womanist merits of women characteristics who have furiously rejected any submission to the cruel conditions imposed upon them during the preIndependence years. Tobe Levin contends that "often in the face of crushing odds, his heroines survive. They are active, intelligent, courageous, defiant" (218).

Wa Thiongo's women characters represent hope and deliver optimism to the other characters. Ultimately, this confirms his womanist belief of Africana women's inputs within life. Accordingly, A Grain of Wheat pinpoints the important tasks done by Kenyan women in different occasions. One of such women is Wambui, the unbelievably struggling, popular heroine who does her best to assist the Mau Mau group. Wambui's nomination as the bravest militant has not happened haphazardly. "During the Emergency, she carried secrets from the villages to the forest and back to the villages and towns. She knew the underground movements in Nakuru, Njoro, Elburgon and other places in and outside the Rift Valley" (23). Wambui's zealous combating, beside Kenyan males, against the White usurpers not only signifies that she just pursues freedom of Kenyan females, but also an attempt to accomplish the freedom of all her fellow citizens. In the light of this, Taiwo Ajai, a Nigerian activist, stresses that Kenyan females' "emancipation is unattainable until the basic rights are provided all [Africana] people" (62-3). Negro womanists seem to be aware of the fact that all Africana natives have grievously endured the bruise and humiliation at the hands of the British.

Wambui is a distinct chivalrous Mau Mau warrior who adopts the Kenyan womanist standpoint "that addresses the needs of black women, men and children," and thus it "can strengthen [their] bonds with one another, deepen ... [their] community and further black liberation" (Hooks, "Feminism" 124). An obvious proof which reveals Wambui's womanist belief appears during the Emergency years when the police stop her at a check point. Her wisdom is crystal clear. In spite of concealing arms in her suitcase, she behaves dauntlessly and brilliantlyHer fierce courage and chivalry are apparent when the British guards have been tempted by her attractive expression. She has said:

The children of these days . . . Have you lost all shame? Just because the whiteman tells you so, you would actually touch your own mother's . . the woman who gave you birth? All right, I'll lift the clothes and you can have a look at your mother, it is so aged, and see what gain it'll bring you for the rest of your life. (A Grain 24)

Thus, A Grain of Wheat accurately presents a fresh portrayal of Kenyan women's accomplishments which are greatly excellent. Wa Thiongo underlines their pivotal achievements for the country's progress. He widens his womanist thoughts to include both the social and the political circles. Moreover, because of her constant notion that Black ladies enjoy exceptional capacities which enable to combat any obstacle ahead, Wambui is 
witnessed urging men to robustly resist the imperialist injustice which steals their toil and pays the least salaries. Contrary to European feminism, Black womanism calls for a rigorous relationship with males in different fields, political or social, in order to avoid the possibility that patriarchal momentary retreat results in a calamitous decline and ceaseless occupation. Wambui says effective words, attempting to trigger males' force . Her rebellious feeling appears brightly, thus:

Wambui suddenly broke through the crowd and led a group of women to the platform. She grabbed the microphone from the speakers. People were interested. Was there any circumcised man who felt water in the stomach at the sight of a white man? Women, she said, had brought their Mithuru and Miengu to the platform. Let therefore such men, she jeered, come forward, wear the women's skirts and aprons and give up their trousers to the women. Men sat rigidly in their seats and tried to laugh with the crowd to hide the inner discomfort. The next day all men stayed away from work. (A Grain 205)

This occasion obviously illustrates Wa Thiongo's trust in the momentous ability of Africana females who can make change. To heighten the description of Kenyan femmes' adeptness, Wa Thiongo interestedly tries to report the hard times they have suffered under the ground during the encounters with the savage occupation troops. Large numbers of Africana females are captured because of their joining the Mau Mau uprising, and consequently they have been jailed in depression and horror. Everybody has been imprisoned in the seizure bases and have been compelled to delve the battlefield ditches. During the tunnel making, they are cruelly tormented and lashed till they died

Comparably, to produce a complete womanist appreciation of the book, Wa Thiongo exhibits Africana women's miseries which heighten their spirit of resolution. Displaying females as bold and perseverant does not signify that they have encountered no problems and sorrows in the occupation reality, however, they have appeared as triumphant albeit the difficult circumstances in the Emergency years. Their unusual advantages enable them to combat these horrible conditions. They have developed within atmospheres that have violently objectified them.

Yet, Mumbi, the typical revolutionary woman, is one of those who challenge destitution and famine so as to remain faithful to her spouse. The shortage in nutrition and bankruptcy have not been able break her firm resolution to combat the diverse obstacles. She emerges as a strong female who is unpredictable to be subjugated. In order not to be bodily harassed, she determines to be a farm laborer in the White men's fields, though insufficiently paid. She ventures, "[w]e worked in their large farms tea-plantations, sometimes digging out Muthangari grass and at times gathering the tea-leaves. With the money I earned, I bought flour which kept the five us alive" (166). Wa Thiongo pictures resentfully the numerous forms of oppression they have been subject to. This grievous fact is displayed herein:
For women, the problem is centered on the fact that the conditions against which they were campaigning were the product of two kinds of oppression which put the antagonists of the nationalist struggle in the same camp: patriarchal systems of exploitation were common to both colonial regimes and indigenous societies. Women therefore had to fight the double colonization of patriarchal domination in its local as well as its imperial forms. (Young 379)

Actually, it seems extremely sorrowful to be physically harassed by one of your natives who are believed to be providers of safety and defense. Mumbi has been pressed by various enticement by Karanja yet she has rejected every attempt by him, resolutely intending "not to accept any more help from Karanja, who by now had worked his way up and was the leader of the homeguards" (A Grain 166). But, being overwhelmed by joy when her espouse has been surprisingly freed allows Karanja the opportunity to subdue her bodily. This physical ravishment correlates to the traitorousness referred to in Harold Pinter's Betrayal (1978). In this drama, Pinter depicts the erotic affair of Jerry and his comrade's espouse Emma. He deprecates Emma for her bold act of proving false to her spouse, missing all sorts of loyalty. To the opposite of Emma, Mumbi does not decide to deceive her spouse premeditatedly, yet she has been cunningly snookered by karanja's satanic machination. "[I]n giving herself to karanja at the time when he brings her the news of Ginkoyo's release from prison, the sexual encounter became the illuminate extension of her supreme joy in hearing of her husband's release and karanja becomes merely an agent in the process" (Killam 67). This is a strong proof of her loyalty to her spouse.

In reality, Kenyan ladies are bullied by Black males' oppression. Surely Kenyan males are influenced by the inherited notions of the man-dominated community notwithstanding their big infatuation with females. For example, Gikonyo's long-piercing affliction in the military prison is relieved only when imagining his return home to his sweetheart Mumbi. In spite of this, the whole of this daydreaming vanishes. Despite his being intensely pleased to be with her after many years of imprisonment, Gikonyo is infuriately shocked by the sight of a baby placed on her back. He, immediately, charges her of committing adultery. This signifies that this Kenyan husband, Gikonyo, "is haunted by visions of Mumbi responding passionately to Karanja's body" (Robson 58). Consequently, Kenyan wives are humiliated by their spouses who violently beat them to exhibit their male authority. As a result, this man-enacted suppression is observed in the unsettled links of males and ladies. Gikonyo does not give her any opportunity to advocate herself or at least allow her any time to describe what has truthfully occurred. His extravagant patriarchal arrogance abstains him from hearing the real story of having this baby. This leads to living in a troubled family home lacking any kind of interaction. As Pauline Ada Uwakweh suggests:

Silencing comprises all imposed restrictions on women's social being, thinking and expressions that are religiously or culturally sanctioned. As a patriarchal weapon of control, it is 
used by the dominant male structure on the subordinate or muted female structure. (qtd. in Okuyade 248)

\section{Conclusion}

To conclude, this paper displays Wa Thiongo's Black womanist outlook by looking at the novels' characteristics. Through examining the narrative characterization, one may infer that Kenyan womanists are united with their men in the public progress. Despite enduring harsh circumstances, Kenyan femmes adopt the primary womanist attitude. They have witnessed cruel communal, public, and financial conditions, but they continue to struggle actively. The Emergency period produces a pejorative effect on all community members, yet through the national fight and robust unity; dauntlessly they pass all obstacles and so obtain Independence which is not just for Kenyan females, but for the whole society too. Plainly speaking, by embracing the Black womanist outlook, the whole Negros can now reform the current reality and portray a flourishing picture of the coming days.

A Grain of Wheat includes a number of the features of Black Womanism hypothesis which encourages the cooperation among the whole Kenyan citizens so as to reach self-autonomy. Its female characteristics express esteem for old people, are connected with males in resistance, and are dedicated to the public fight. They believe in the idea that they must receive every acclaim and respect. But for their distinguished deeds within the Mau Mau movement, they could not have made any success. Despite bearing aggressive conditions, Africana females have made unbelievable achievements in the socio-political circles. In case the readers ponder over the whole of their trials of overcoming the entire demeaning powers, they can take invaluable messages. Herein, Wa Thiongo shows a sharp awareness of the public tasks of Africana femmes during the Emergency years. Throughout A Grain of Wheat, one may notice the memorable endeavor of Black ladies and their dedication to the public freedom in collaboration with their Kenyan partners.

Hence, the patriotic merits of the feminine characteristics and their eagerness for freedom have clearly appeared in many supportive events which symbolize their Kenyan stances. By depicting the characteristics of Mumbi, Gikonyo, Wambui, Warui, Wa Thiongo displays his womanist opinions. Due to the sense of unification prevailing the entire community, the pursuit of autonomy does not vanish notwithstanding the cruel difficulties in the Emergency years. This attracts the readers' curiosity and invites them to inquire about the effect of the post-Independence period on Kenyan femmes' destiny. The inquiry addressed how far this fresh era will be filled with liberty for the Black nation generally and Kenyan females particularly, or it can deplore their atmosphere. In fact, this will be sufficiently explored in the next chapter that examines the position of Kenyan ladies in the postcolonial era, relying upon some other Black womanist marks. It focuses on studying the womanist demeanor of Africana female characteristics during this serious era so as to secure the persistence of Wa Thiongo's womanist views. Importantly, the next chapter aims to uncover the true influence of Independence on Kenyan ladies and how they have employed the womanist merits to be able to challenge all obstacles of this critical phase.

\section{References}

[1] Ajai, Taiwo. (1981)"The Voluptuous Ideal." One is Not a Woman, One Becomes: The African Woman in a Transitinal Society: African Women Tell Their Story, edited by Daphne W. Ntiri, Bedford Publishers, pp. 62-3.

[2] Allan, Tuzyline Jita.( 1995) Womanist and Feminist Aesthetics: A Comparative Review. Ohio University Press,. p.88

[3] Elkins, Caroline. Imperial Reckoning: The Untold Story of Britain's Gulag in Kenya. Henry Holt and Company,

[4] Hooks, Bell. (1992 )“Feminism - It's a Black Thing!” Essence, vol. 23 , no. 3 , , p. 124

[5] Feminist Theory from Margin to Center(1984). South End Press,

[6] Hudson-Weems, Clenora.( 1997) "Africana Womanism and The Critical Need for Africana Theory and Thought." The Western Journal of Black Studies, vol. 2, no. 2, , p. 96.

[7] Killam, G. D.( 1980) An Introduction to the Writings of Ngugi. Heinemann

[8] Levin, Tobe.( 1986) "Women as Scapegoats of Culture and Cult: An Activist's View of Female Circumcision in Ngugi's The River Between." Ngambika: Studies of Women in African Literature, edited by Carole Boyce Davis and Anne Adams Graves, Africa World, , p. 218

[9] Monkman, Leslie.( 2019) "Kenya and the New Jerusalem in A Grain on Wheat." African Literature Today, vol. 7, no. 1, 1975, p. 113, www.jstor.org/stable/3819032. Accessed 14 Nov.

[10] Okuyade, Ogaga.( 2020) "Changing Borders and Creating Voices: Silence as a Character in Chimamanda Adichie's Purple Hibiscus." The Journal of Pan African Studies, March 2009, p. 248, www.questia.com/library/journal/1P3-1684025361/changingborders-and-creating-voices-silence-as-character. Accessed 2 Jan.

[11] Robson, Clifford B.( 1979) Ngugi Wa Thiongo. Macmillan,.

[12] Thiongo, Ngugi Wa(1967). A Grain of Wheat. Heinemann,.

[13] Thiongo, Ngugi (2009)"Email interview with Ngugi Wa Thiong'o." Women and Patriarchal Power in the Selected Novels of Ngugi Wa, by Mugambi Albert Rutere.

[14] Preface. Secret lives and Other Stories. Lawrence Hill, 1975.

[15] Young, R.( 2004 ) White Mythologies: Writing History and the West. Routledge 